\title{
Strategi Penghidupan Berkelanjutan Masyarakat Berbasis Aset di Sub DAS Pusur, DAS Bengawan Solo
}

\author{
Rathna Wijayanti ${ }^{1}$ \\ Program Studi S3 IImu Lingkungan \\ Universitas Gadjah Mada, Yogyakarta, Indonesia
}

\section{Baiquni}

Fakultas Geografi

Universitas Gadjah Mada, Yogyakarta, Indonesia

\author{
Rika Harini \\ Fakultas Geografi \\ Universitas Gadjah Mada, Yogyakarta, Indonesia
}

Artikel Masuk : 18 Juni 2016

Artikel Diterima : 8 Agustus 2016

Publikasi Online : 31 Agustus 2016

\begin{abstract}
Abstrak: Menghadapi ketidakcukupan air dan masalah sosial ekonomi budaya, petani di Sub DAS Pusur berstrategi dengan mengkombinasikan aset penghidupan yang dimiliki dan yang dapat di akses. Penelitian bertujuan mengkaji kondisi aset penghidupan yang dimiliki dan yang dapat diakses oleh masyarakat, serta mengkaji strategi penghidupan berkelanjutan masyarakat berbasis aset untuk meningkatkan penghidupan dan menjaga keberlanjutan lingkungan di Sub DAS Pusur, DAS Bengawan Solo. Metode yang digunakan adalah analisis kuantitatif dan kualitatif terhadap data hasil kuisioner, wawancara mendalam, dan observasi. Variabel untuk menilai kondisi aset penghidupan meliputi modal manusia, modal alam, modal sosial, modal fisik, dan modal keuangan. Strategi penghidupan dikelompokkan menjadi intensifikasi/ ekstensifikasi, diversifikasi, dan migrasi. Metode area sampling dan purposive sampling digunakan dengan membagi daerah penelitian menjadi tiga yaitu bagian atas, tengah, dan bawah. Hasil penelitian menunjukkan bahwa aset tertinggi dimiliki oleh sub DAS bagian tengah, kemudian atas, dan terakhir bawah. Modal fisik memiliki nilai tertinggi di seluruh bagian sub DAS jika dibandingkan modal yang lain. Strategi intensifikasi pada bagian atas berupa agroforestri sedangkan pada bagian tengah dan bawah menggunakan panca usaha tani. Strategi diversifikasi pada bagian atas dengan cara beternak sedangkan bagian tengah dan bawah dilakukan dengan menjadi buruh/ karyawan. Strategi migrasi dengan alasan menikah dominan untuk bagian atas dan bawah, sedangkan bagian tengah migrasi karena alasan pekerjaan.
\end{abstract}

Kata Kunci: aset penghidupan, ketidakcukupan air, strategi rumah tangga petani

\footnotetext{
${ }^{1}$ Korespondensi Penulis: Program Studi S3 Ilmu Lingkungan, Universitas Gadjah Mada, Yogyakarta, Indonesia Email: wijayanti.rathna@yahoo.com
} 


\begin{abstract}
In coping with water insufficiency and socio-economic culture problems, the strategy by combining the livelihoods assets which they have already owned and which are accessible has applied by the farmers at Pusur Sub-Watershed. The study aims to review the conditions of livelihoods assets owned and those which were accessible by the community, as well as to review the strategies of sustainable livelihoods of communitybased on the asset in order to increase the living and to protect the environment sustainability in Pusur Sub-Watershed, Bengawan Solo Watershed. The method used was using quantitative and qualitative analysis through the questionnaire, in-depth interview, and observation techniques. The variables are used to value the condition of livelihoods assets are the human capital, natural capital, social capital, physical capital, and financial capital. The livelihood strategies were grouped into an intensification and extensification, diversification, and migration. The method of sampling area and purposive sampling are applied to split the area of research into three, i.e. the upper part, middle part, and bottom part. The result showed that the highest asset owned by Sub-Watershed on the middle part, upper and the last is a bottom part. The physical capital would have the highest value in the whole area of Sub-Watershed if it compared to the other capitals. The intensification strategy on the upper part is agroforestry, while the middle and bottom have "panca usaha tani" strategy. The diversification strategy through livestock is taken in the upper part, while the strategies as the employee or hourly workers are found in the middle and bottom part. The migration strategies with the reason of marriage were dominating in the bottom and upper parts, while the middle part the migration is due to the work issues.
\end{abstract}

Keywords: assets-based, water insufficiency, livelihoods strategy

\title{
Pendahuluan
}

Menyadari bahwa kemampuan pemerintah terbatas dalam pengelolaan Daerah Aliran Sungai (DAS), terlebih untuk Sub DAS atau DAS bukan prioritas, pendekatan penghidupan berkelanjutan dapat dijadikan sebagai pilihan inovatif untuk pengelolaan DAS dan meningkatkan kesejahteraan manusia. Pendekatan ini memperhatikan aset yang dimiliki dan yang dapat diakses oleh masyarakat dalam melangsungkan hidupnya serta mempertimbangkan keberlanjutan pengelolaan sumber daya sosial dan kelembagaaan serta sumber daya alam (SDA) (Saragih, Lassa, \& Ramli, 2007). Berbagai studi mengenai penghidupan berkelanjutan dilakukan antara lain oleh Baiquni (2006), Saleh (2016), dan Abdurrahim (2015). Studi-studi tersebut menekankan pada peningkatan penghidupan masyarakat perdesaan, namun belum ada yang berorientasi pada pengelolaan DAS.

Pengelolaan DAS adalah pendekatan yang holistik untuk mengelola sumber daya DAS dengan mengintegrasikan kehutanan, pertanian, peternakan, dan pengelolaan air, yang dapat diperluas untuk pembangunan pedesaan yang terkait erat dengan penghidupan masyarakat lokal (Pandit, Wagley, Neupane, \& Raj, 2007). Sub DAS Pusur, DAS Bengawan Solo berada di wilayah Kabupaten Klaten $(80,19 \%)$ dan Boyolali $(19,80 \%)$ Provinsi Jawa Tengah, mencakup 7 (tujuh) kecamatan dan 60 desa di dalamnya. Luas Sub DAS adalah $5.781 \mathrm{Ha}$ dan termasuk kategori DAS sangat kecil $(<10.000 \mathrm{Ha})$ dengan bentuk DAS sempit dan memanjang kurang lebih $30 \mathrm{~km}$. Sub DAS Pusur memiliki posisi yang strategis dalam tata air karena memiliki sejumlah sumber mata air yang dipergunakan untuk berbagai keperluan, seperti bahan baku air minum, irigasi untuk pertanian, perikanan, industri, dan pariwisata. Air yang dihasilkan tidak hanya dinikmati oleh masyarakat di Sub DAS Pusur namun hingga lintas batas sub DAS dan lintas batas administrasi. Sebagai contoh, air dari sumber mata air Cokro telah menjadi bahan baku air bersih untuk masyarakat Kabupaten Surakarta, Kota Solo, dan sekitarnya sejak dibangunnya PDAM Kota Surakarta oleh Paku Buwono X pada Tahun 1929 (PDAM Kota Surakarta, 2016). 
Peran Sub DAS dalam menopang ketahanan pangan juga sangat besar.Sejarah mencatat daerah Delanggu dan sekitarnya dikenal dengan sebutan "lumbung padi", penghasil beras-beras berkualitas, antara lain beras delanggu, raja lele, mentik wangi, dan lain-lain. Persentase lahan pertanian mencapai $72,25 \%$ luas wilayah dengan dominasi ekpresi topografis datar sampai landai, 86,29\% jenis tanah merupakan regosol kelabu yang bersifat subur dan kaya unsur hara hasil erupsi Gunung Merapi (Bappeda Kabupaten Klaten, 2010). Dengan potensi lahan tersebut serta didukung banyaknya sumber air menjadikan sub DAS ini sebagai daerah pertanian yang potensial.

Ditinjau per bagian sub DAS, sejak dulu sub DAS bagian atas memiliki akses air permukaan maupun air tanah yang sulit. Hal ini berbeda dengan sub DAS bagian tengah dan bawah yang merupakan pertanian lahan basah dengan irigasi sepanjang tahun. Namun, seiring berjalannya waktu, para petani di bawah seringkali menghadapi permasalahan kekurangan air di beberapa tempat dan pada periode tertentu, berakibat pada penurunan produksi pertanian. Hal ini terjadi akibat kondisi yang dipicu kecenderungan ketersediaan sumber daya air yang makin terbatas, pertambahan jumlah pemakai, penggunaan air untuk peruntukan baru, dan kondisi saluran yang makin buruk.

Di Klaten, permasalahan menurunnya ketersediaan air telah menyebabkan kegiatan penanaman padi pada musim tanam ketiga (MT III) di bagian bawah Sub DAS Pusur tidak dapat dilaksanakan jika tidak ada pemberian irigasi suplementer dari air tanah. Hal ini ironis sekali mengingat potensi air di Kabupaten Klaten, terutama di bagian tengah Sub DAS sangat melimpah karena banyaknya sumber mata air dan aliran sungai mengalir sepanjang tahun (Sosiawan \& Kartiwa, 2011). Masalah lain adalah terjadinya konflik pemanfaatan air sejak beroperasinya PT. Tirta Investama pada Tahun 2002 dengan masyarakat terutama petani. Perusahaan ini merupakan Group Aqua Danone yang merupakan perusahaan multinasional yang mengantongi ijin privatisasi air dan mengambil air tanah untuk produksi Air Minum Dalam Kemasan (AMDK). Masyarakat meyakini bahwa penyebab ketidakcukupan air beberapa tahun terakhir adalah akibat kegiatan pengambilan air tanah yang menurunkan kuantitas air di DAS Pusur dan sekitarnya (Meida, 2012).

Sub DAS bagian atas memiliki fungsi sebagai daerah resapan air (recharge area), namun kawasan yang benar-benar berfungsi sebagai hutan tidak ditemui. Penggunaan lahan didominasi kebun campur dengan mengandalkan air hujan sebagai sumber pengairannya. Keterbatasan ketersediaan air tidak hanya untuk pertanian, namun juga untuk keperluan domestik dan peternakan. Kegiatan agroforestri yang dikembangkan oleh masyarakat cukup berhasil bahkan beberapa tahun terakhir beberapa tamu datang untuk melakukan studi banding, tidak hanya tamu dari dalam negeri namun juga dari luar negeri, dan terbukti sistem agroforestri ini mampu mengangkat kesejahteraan masyarakat. Sub DAS bagian tengah dan bawah merupakan kawasan budidaya pertanian lahan basah. Perbedaan kedua bagian sub DAS ini adalahsub DAS bagian tengah tercukupi oleh irigasi teknis sepanjang tahun, sedangkan sub DAS bagian bawah menggunakan irigasi campuran.

Guna memperjuangkan penghidupan yang berkelanjutan dan mengatasi kerentanan terkait ketersediaan air tersebut, mayoritas masyarakat yang bermatapencaharian sebagai petani dituntut melakukan strategi untuk penghidupannya. Strategi penghidupan menggambarkan upaya yang dilakukan masyarakat dalam mencapai penghidupan yang memadai. Strategi penghidupan berkaitan dengan bagaimana masyarakat mengelola atau mengkombinasikan aset penghidupan yang tersedia atau dimiliki, mensikapi perubahan yang terjadi, dan menentukan prioritas untuk mempertahankan atau memperbaiki penghidupan (Scoones, 1998; Scale Up, 2011). Aset penghidupan merupakan segala sesuatu yang berharga atau merupakan sekumpulan modal yang digunakan melangsungkan penghidupan. Aset penghidupan terdiri dari 5 (lima) modal, yaitu modal manusia (human capita), modal sosial (social capital), modal alam (natural capita), modal fisik (physical capita), dan modal finansial (financial capital) (DFID, 2001). 


\section{Strategi Penghidupan Berkelanjutan Masyarakat Berbasis Aset di Sub DAS Pusur, DAS Bengawan Solo}

Aktivitas dalam penghidupan berkelanjutan merupakan strategi penghidupan yang berupa pilihan cara berdasar prioritas dan adanya kesempatan dalam menggunakan kemampuan atau aset yang tersedia untuk mempertahankan atau memperbaiki penghidupan. Setiap individu dapat memiliki strategi penghidupan yang berbeda, tergantung aset penghidupan yang tersedia dan kerentanan yang dihadapi. Berdasarkan strategi yang digunakan, beberapa ahli mengelompokkan strategi sebagai berikut:

- Scoones (1998) mengelompokkan strategi berdasarkan kegiatan untuk meningkatkan pendapatan yaitu intensifikasi dan ekstensifikasi, diversifikasi, dan migrasi.

- White (1991) mengelompokkan strategi berdasarkan status sosial ekonomi rumah tangga yaitu survival, konsolidasi, dan akumulasi.

- Ellis (2000) mengelompokkan strategi berdasarkan basis aktivitas yaitu berbasis natural resources dan non natural resources.

- Bank Dunia (2010) mengelompokkan strategi berdasarkan adaptasi yang dilakukan, yaitu reaktif/responsif dan proaktif/antisipatif

Pendekatan penghidupan berkelanjutan untuk melihat strategi masyarakat dalam konteks pengelolaan DAS, dalam penelitian ini dilakukan di Sub DAS Pusur, menggunakan aset penghidupan merupakan hal yang menarik untuk dikaji. Penelitan ini memiliki tujuan:

1. Mengkaji aset penghidupan yang dimiliki dan yang dapat diakses oleh masyarakat, yang meliputi modal manusia, modal alam, modal, modal sosial, dan modal fisik.

2. Mengkaji strategi penghidupan berkelanjutan masyarakat berbasis aset untuk meningkatkan penghidupan dan menjaga keberlanjutan lingkungan.

\section{Metode Penelitian}

Metode penelitian yang digunakan adalah metode kualitatif dan kuantitatif. Teknik area sampling digunakan untuk membagi daerah penelitian dibagi menjadi 3 (tiga) bagian, yaitu bagian atas, tengah, dan bawah berdasarkan pertimbangan dominasi penggunaan lahan dan sumber pengairan untuk lahan pertanian. Desa sampel dipilih secara purposive dari tiap bagian sub DAS, bagian atas diwakili oleh Desa Sukorejo yang didominasi oleh pertanian lahan kering tadah hujan, bagian tengah diwakili oleh Desa Keprabon yang didominasi sawah dengan pengairan irigasi sepanjang tahun, dan bagian bawah diwakili oleh Desa Taji yang didominasi sawah dengan sumber pengairan campuran, yaitu berasal dari irigasi, tadah hujan, dan pompa. Populasi penelitian adalah rumah tangga petani di lokasi penelitian.

Data primer diperoleh dari wawancara terstruktur, wawancara mendalam, observasi, dan dokumentasi. Responden dari 3 (tiga) desa sampel sebanyak 102 rumah tangga petani, yang dipilih berdasarkan teknik random sampling. Pemilihan jumlah sampel berdasarkan pernyataan beberapa ahli bahwa besarnya jumlah sampel minimun adalah $10 \%$ dari populasi untuk penelitian deskriptif, 30 objek untuk penelitian korelasi, 30 subjek per grup untuk penelitian kausal perbandingan, dan 15 subjek per grup untuk penelitian eksperimental (Gay \& Diehl, 1992; Fraenkel \& Wallen, 1993). Wawancara mendalam dilakukan terhadap 31 orang key persons yang dianggap dapat memberikan informasi yang berkaitan dengan tujuan penelitian. Selain data primer, digunakan data sekunder yang diperoleh dari studi pustaka dan dokumen yang diterbitkan oleh lembaga penelitian dan pemerintah.

Data yang diperoleh dianalisis secara kualitatif dan kuantitatif. Teknik analisis data secara deskriptif kuantitatif dilakukan dengan memberi skor 0 sampai 4 dengan asumsi bahwa semakin mendukung suatu unsur akan semakin besar skornya. Untuk menyamakan bobot penghitungan dan memudahkan interpretasi, hasil skoring dikonversi dalam nilai dengan skala 0 (nol) sampai 10 (sepuluh). Teknik analisis kualitatif digunakan untuk menafsirkan data sesuai dengan tujuan penelitian baik yang berasal dari kuesioner, 
wawancara, maupun pengamatan, disamping untuk mendeskripsikan suatu fenomena, dan untuk cross check dengan hasil kuisioner. Tabel 1 menjelaskan tujuan penelitian, data, sumber data dan analisis yang digunakan secara lebih rinci dalam penelitian.

Tabel 1. Tujuan Penelitian, Variabel, Data yang Dikukur, Sumber Data, dan Analisis

\begin{tabular}{|c|c|c|c|c|}
\hline Tujuan & Variabel & Data yang Diukur & $\begin{array}{c}\text { Sumber dan Cara } \\
\text { Pengumpulan Data }\end{array}$ & Analisis \\
\hline \multirow[t]{5}{*}{$\begin{array}{l}\text { Aset } \\
\text { Penghidupan }\end{array}$} & $\begin{array}{l}\text { Modal } \\
\text { manusia }\end{array}$ & $\begin{array}{l}\text { Pendidikan, kesehatan, } \\
\text { pengalaman, pengetahuan, } \\
\text { ketrampilan/keahlian, tenaga } \\
\text { kerja, karakter } \\
\text { diri/motivasi/inovasi, dan } \\
\text { kemampuan fisik }\end{array}$ & $\begin{array}{l}\text { Wawancara } \\
\text { terstruktur } \\
\text { menggunakan } \\
\text { kuisioner; }\end{array}$ & $\begin{array}{l}\text { Deskriptif } \\
\text { kuantitatif dan } \\
\text { kualitatif }\end{array}$ \\
\hline & Modal alam & $\begin{array}{l}\text { Penguasaan lahan, } \\
\text { produktivitas lahan,sumber } \\
\text { air, danjasa lingkungan }\end{array}$ & $\begin{array}{l}\text { - Wawancara } \\
\text { mendalam; }\end{array}$ & \\
\hline & Modal sosial & $\begin{array}{l}\text { Organisasi masyarakat, } \\
\text { partisipasi, gotong royong, } \\
\text { hubungan kekerabatan, } \\
\text { jaringan sosial }\end{array}$ & $\begin{array}{l}\text { - Observasi } \\
\text { lapangan }\end{array}$ & $\begin{array}{l}\text { Analisis } \\
\text { meliputi } \\
\text { besarnya aset } \\
\text { yang dimiliki }\end{array}$ \\
\hline & $\begin{array}{l}\text { Modal } \\
\text { Finansial }\end{array}$ & $\begin{array}{l}\text { Penghasilan, pengeluaran, } \\
\text { tabungan, hutang-piutang, } \\
\text { bantuan }\end{array}$ & - Data sekunder & $\begin{array}{l}\text { dan yang } \\
\text { dapat diakses }\end{array}$ \\
\hline & Modal Fisik & $\begin{array}{l}\text { Sarana dan prasarana, } \\
\text { peralatan kerja/produksi, } \\
\text { aksesibilitas }\end{array}$ & & \\
\hline \multirow[t]{3}{*}{$\begin{array}{l}\text { Strategi } \\
\text { penghidupan } \\
\text { masyarakat }\end{array}$} & $\begin{array}{l}\text { Intensifikasi } \\
\text { dan } \\
\text { ekstensifikasi }\end{array}$ & $\begin{array}{l}\text { - Pemanfaatan lahan } \\
\text { pertanian yang ada } \\
\text { - Pemanfaatan lahan } \\
\text { pekarangan } \\
\text { - Pemanfaatan lahan } \\
\text { kosong } \\
\text { - Penambahan lahan } \\
\text { garapan }\end{array}$ & $\begin{array}{l}\text { - Wawancara } \\
\text { terstruktur } \\
\text { menggunakan } \\
\text { kuisioner; } \\
\text { - Wawancara } \\
\text { mendalam; } \\
\text { - Observasi } \\
\text { lapangan }\end{array}$ & $\begin{array}{l}\text { Deskriptif } \\
\text { kuantitatif dan } \\
\text { kualitatif }\end{array}$ \\
\hline & Diversifikasi & $\begin{array}{l}\text { - Penghasilan diluar } \\
\text { pertanian (peternakan, } \\
\text { perikanan, jasa, } \\
\text { perdagangan, karyawan) } \\
\text { - Pengolahan hasil } \\
\text { pertanian } \\
\text { - Penghasilan dari modal } \\
\text { - Penambahan jam kerja } \\
\text { dan kerja sampingan }\end{array}$ & - Data sekunder & $\begin{array}{l}\text { Analisis } \\
\text { meliputi } \\
\text { aktivitas, } \\
\text { penggunaan } \\
\text { aset, dan } \\
\text { strategi yang } \\
\text { dipilih dalam } \\
\text { meningkatkan } \\
\text { penghidupan }\end{array}$ \\
\hline & Migrasi & $\begin{array}{l}\text { - Mobilitas sirkuler/ } \\
\text { komuter } \\
\text { - Migrasi permanen }\end{array}$ & & \\
\hline
\end{tabular}




\section{Hasil dan Pembahasan}

\section{Kondisi Aset Penghidupan Rumah Tangga}

Aset penghidupan rumah tangga (RT) di setiap bagian sub DAS bervariasi tergantung dari nilai tiap modal yang dimiliki masyarakat, yaitu modal manusia, modal sosial, modal alam, modal fisik, dan modal finansial. Beragam hubungan dan keterkaitan satu sama lain yang dimiliki antar komponen sumber daya penghidupan tersebut diGambarkan dalam pentagon aset. Bentuk segilima dan garis yang saling menghubungkan dengan titik pusat ditengah bidang pentagon tersebut menggambarkan variasi tingkat kepemilikan dan akses masyarakat terhadap sumber daya (DFID, 2001). Hasil penelitian (Tabel 2) menunjukkan bahwa aset penghidupan yang memilikinilai paling tinggi di bagian tengah $(28,07)$, kemudian bagian atas $(25,50)$, dan bagian bawah $(23,37)$. Gambar 1 menunjukkan pentagon aset di 3 bagian Sub DAS Pusur

Tabel 2. Nilai Aset Penghidupan Rumah Tangga Tiap Bagian Sub DAS

\begin{tabular}{lccc}
\hline \multirow{2}{*}{ Modal } & \multicolumn{3}{c}{ Nilai skala } \\
\cline { 2 - 4 } & Atas & Tengah & Bawah \\
\hline Manusia & 5,45 & 5,61 & 5,18 \\
Alam & 4,82 & 6,52 & 5,24 \\
Sosial & 3,91 & 5,83 & 4,63 \\
Finansial & 3,77 & 3,52 & 2,42 \\
Fisik & 7,56 & 6,61 & 5,90 \\
Jumlah & $\mathbf{2 5 , 5 0}$ & $\mathbf{2 8 , 0 7}$ & $\mathbf{2 3 , 3 7}$ \\
\hline
\end{tabular}

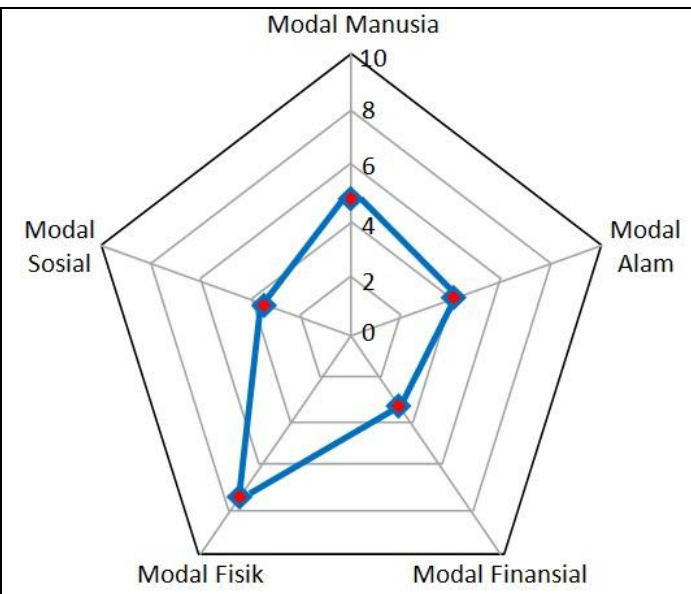

Pentagon aset bagian atas

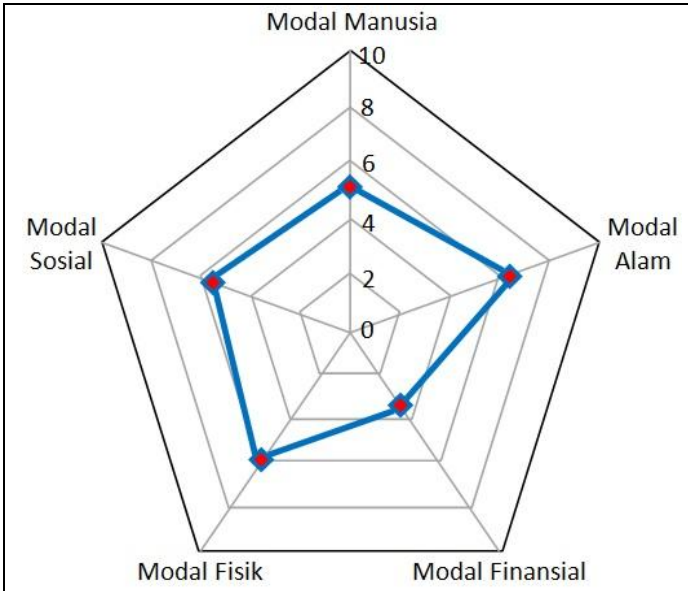

Pentagon aset bagian tengah

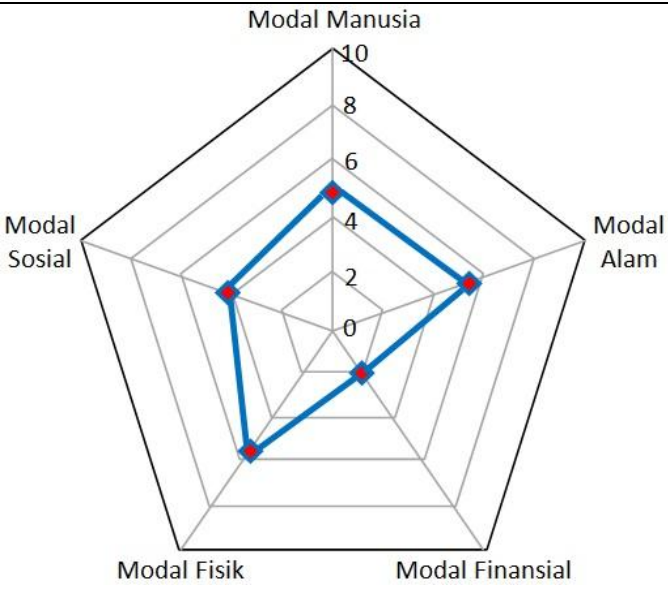

Pentagon aset bagian bawah

Sumber: Hasil Analisis Data Primer, 2016

Gambar 1. Pentagon Aset di 3 Bagian Sub DAS Pusur Tahun 2016 


\section{Modal Manusia (Human Capital)}

Pendekatan penghidupan (livelihoods approach) memiliki perhatian yang pertama dan utama pada manusia (people center) sebagai subyek yang penting. Modal manusia menunjukkan kemampuan seseorang dalam memperoleh akses yang lebih baik terhadap kondisi penghidupan mereka (Baiquni, 2006). Sebagai modal terpenting dalam penghidupan yang memungkinkan seseorang melaksanakan strategi penghidupan serta mencapai tujuan penghidupan mereka, modal manusia juga diperlukan untuk mengolah empat aset penghidupan lainnya (DFID, 1999a). Dalam penelitian ini, modal manusia dinilai dari variabel pendidikan, kesehatan, pengalaman, pengetahuan atau ketrampilan, tenaga kerja, dan karakter diri/ motivasi/ inovasi. Kualitas manusia perlu terus ditingkatkan agar pengelolaan aset berdayaguna dan lestari keberlanjutannya.

Tabel 3. Nilai Variabel Penyusun Modal Manusia

\begin{tabular}{lccc}
\hline \multirow{2}{*}{\multicolumn{1}{c}{ Variabel }} & \multicolumn{3}{c}{ Nilai skala } \\
\cline { 2 - 4 } Pendidikan & Atas & Tengah & Bawah \\
\cline { 2 - 4 } Kesehatan & 5,07 & 5,63 & 4,78 \\
Pengalaman & 10,00 & 9,84 & 9,86 \\
Pengetahuan/ketrampilan & 6,79 & 6,02 & 5,83 \\
Tenaga kerja & 4,61 & 4,09 & 4,12 \\
Karakter diri/motivasi/inovasi & 2,47 & 3,00 & 2,57 \\
Total nilai & 3,76 & 5,06 & 3,92 \\
Rata-rata & 32,69 & 33,64 & 31,08 \\
Sumber: Data Primer, 2016 & $\mathbf{5 , 4 5}$ & $\mathbf{5 , 6 1}$ & $\mathbf{5 , 1 8}$ \\
\hline
\end{tabular}

Mencermati Tabel 2, Tabel 3,dan Gambar 1, nilai modal tertinggi manusiaterdapat di bagian tengah, dan paling rendah dimiliki $\mathrm{RT}$ responden di bagian bawah.Tingkat pendidikan responden di bagian atas dan tengah terbanyak adalah lulusan SLTA sedangkan di bagian bawah terbanyak adalah lulusan SD. Tingkat pendidikan ini didukung dengan lamanya pengalaman bertani. Pengalaman usaha tani responden di daerah penelitian tinggi yaitu 15-30 tahun. Hal ini menunjukkan bahwa responden sangat berpengalaman dalam bidang pertanian. Pengalaman ini merupakan modal dasar untuk dapat meningkatkan produktivitas pertanian. Semakin banyak pengalaman seorang petani akan memiliki modal yang kuat untuk dapat mengatasi kesulitan atau permasalahan dalam bertani.

Dengan pengalaman tersebut, petani sudah terbiasa mengolah lahan pertaniannya untuk mengatasi kendala-kendala yang muncul di lapangan. Namun, mengandalkan pengalaman itu pula keadaan pertanian di Sub DAS Pusur masih berupa pertanian budaya. Pengalaman turun termurun dijadikan pegangan dalam melakukan usaha tani. Gerakan perubahan seperti budidaya padi organik maupun pola tanam "jajar legowo", masih sulit diterapkan karena kurangnya wawasan petani dan hasilnya dinilai kurang signifikan. Dorongan untuk memenuhi kebutuhan ekonomi dan sosial terkadang menyebabkan sikap pengabaian terhadap kelestarian lingkungan, seperti pemakaian pestisida yang menyebabkan tanah mengalami kejenuhan bahan kimia.

Kondisi kesehatan responden di daerah penelitian sangat baik. Sebanyak 99,05\% menyatakan diri mereka sehat dan 98,96\% tidak memiliki penyakit. Jumlah tenaga kerja RT responden memiliki nilai paling rendah diantara unsur penyusun modal manusia, jumlah ini menunjukkan banyak sedikitnya potensi tenaga kerja yang tersedia di dalam keluarga. 
Jumlah anggota RT responden yang mampu bekerja dan menghasilkan penghasilan di bagian atas dan bawah rata-rata 2 (dua) orang sedangkan RT responden daerah tengah hanya 1 (satu) tenaga kerja. Semakin banyak jumlah anggota keluarga produktif yang membantu usaha tani maka biaya tenaga kerja semakin banyak berkurang karena kebutuhan untuk membayar tenaga sewa berkurang. Biaya tersebut dapat dialokasikan untuk keperluan lain. Tenaga kerja yang berasal dari keluarga petani ini merupakan sumbangan keluarga pada produksi pertanian secara keseluruhan dan tidak pernah dinilai dalam uang. Peran anggota keluarga tani ini adalah sebagai aset utama dalam mengelola usaha tani secara bersama. Ada kecenderungan generasi muda lulus sekolah banyak memilih bekerja di luar sektor pertanian dengan alasan hasil pertanian kurang menjanjikan danlebih bergengsi jika bekerja diluar pertanian baik sebagai karyawan pabrik/ wiraswasta.

Istri atau wanita memiliki berperan dalam membantu perekonomian keluarga. Untuk RT respondendi bagian atas dan bawah rata-rata bantuan masih fokus pada pekerjaan di lahan pertanian sedangkan di bagian tengah mengerjakan pekerjaan home industry, seperti pembuatan souvenir gantungan kunci, dompet, kipas, cempurit, wayang, dan gamelan. Istri atau wanita di bagian atas aktif tergabung dalam kelompok tani wanita (KWT) yang produktif menghasilkan bibit tanaman dan pemanfaatan lahan pekarangan. Di bagian bawah, wanita usia dibawah 30 tahun bekerja sebagai buruh di pabrik di Kabupaten Sukoharjo sedangkan yang berumur lebih tua sebagai buruh di sawah.Sulitnya mencari tenaga kerja di bidang pertanian terutama di bagian tengah menyebabkan kegiatan tanam serempak sulit dilakukan. Disisi lain, mesin, seperti alat tanam tidak bisa digunakan ketika tanah jenuh air.

\section{Modal Alam (Natural Capital)}

Modal alam merupakan persediaan alam yang menghasilkan dayadukung dan nilai manfaat bagi penghidupan manusia (DFID, 2001). Modal alam meliputi sumber daya lahanyang terdiri dari penguasaan lahan dan produktivitas lahan, sumber daya air, dan jasa lingkungan (Tabel 4). Rumah tangga sub DAS bagian tengah memiliki total nilai aset alam paling tinggi $(6,52)$ sedangkan bagian atas adalah yang paling rendah $(4,82)$. Hal ini dikarenakan bagian tengah memiliki sumber daya air yang melimpah baik yang berasal dari mata air maupun dari sungai yang dimanfaatkan untuk berbagai keperluan seperti bahan baku air minum, irigasi untuk pertanian, perikanan, industri, dan pariwisata. Sebaliknya, sub DAS bagian atas sumber air untuk pertanian seluruhnya berasal dari air hujan sehingga merupakan lahan kering tadah hujan, tidak memiliki akses irigasi, dan air untuk kebutuhan domestik diakses dengan pipanisasi ke rumah-rumah dari pihak swasta pemilik sumur air tanah dalam.Kedalaman sumur mencapai 100 meter dpal.

Tabel 4. Nilai Variabel Penyusun Modal Alam

\begin{tabular}{lccc}
\hline \multirow{2}{*}{\multicolumn{1}{c}{ Variabel }} & \multicolumn{3}{c}{ Nilai skala } \\
\cline { 2 - 4 } & Atas & Tengah & Bawah \\
\hline Penguasaan lahan & 7,43 & 8,24 & 7,54 \\
Produktivitas lahan & 9,36 & 4,35 & 3,43 \\
Sumber daya air & 2,50 & 9,72 & 6,94 \\
Jasa lingkungan & 0,00 & 3,75 & 3,05 \\
Total nilai & 19,29 & 26,06 & 20,96 \\
Rata-rata & $\mathbf{4 , 8 2}$ & $\mathbf{6 , 5 2}$ & $\mathbf{5 , 2 4}$ \\
\hline Sumber: Data Primer, 2016 & & &
\end{tabular}


Ditinjau dari aspek sumber daya lahan, penguasaan lahan (milik, garapan maupun sewa) di bagian tengah adalah yang paling tinggi sedangkan bagian atas paling rendah. Ditinjau dari sumber pengairannya, bagian tengah seluruh lahan sawah (100\%) memiliki akses irigasi penuh sepanjang tahun. Didukung oleh dominasi ekspresi topografis yang datar sampai landai, jenis tanah regosol kelabu yang bersifat subur dan kaya unsur hara hasil erupsi Gunung Merapi menjadikan daerah tengah sangat potensial sebagai lahan pertanian lahan basah. Namun, dilihat dari nilai produktivitas lahannya, lahan kering tadah hujan di bagian atas ternyata memiliki nilai dua kali dibanding lahan sawah beririgasi sepanjang tahun di bagian tengah, dan memiliki nilai hampir tiga kali lebih dibanding lahan sawah dengan irigasi campuran di bagian bawah. Menurut responden, tingkat kesuburan lahan bagian tengah sebesar 28,13\%, masih lebih subur bagian atas $(57,14 \%)$ maupun bagian bawah (28,57\%). Kurang suburnya bagian tengah disebabkan pengolahan lahan sawah tiada henti sepanjang tahun dan pemakaian pupuk kimia yang terus menerus.Lahan di bagian atas tingkat pengolahan lahan tidak terlalu intensif dan pemakaian pupuk untuk tanaman berasal dari pupuk kandang. Kondisi lahan bagian bawah kadang masih sempat diistirahatkan atau diberokan ketika lahan tidak memperoleh air.

Jasa lingkungan di bagian tengah paling tinggi dibanding bagian yang lain, berupa pemanfaatan mata air untuk PAMSIMAS (Penyediaan Air Minum dan Sanitasi Berbasis Masyarakat) serta pemanfaatan sungai untuk arung jeram dan pengairan.PAMSIMAS adalah program dari Kementerian Pekerjaan Umum dan swadaya masyarakat yang mulai berjalan tahun 2012 karena sumur gali tercemar bakteri coli akibat sistem sanitasi yang buruk. Saat ini, sudah banyak rumah tangga yang memiliki sarana MCK meskipun sebagian masyarakat karena faktor budaya masih tetap melakukan MCK di sungai.

\section{Modal Sosial}

Modal sosial adalah sumber daya sosial yang bermanfaat dan digunakan masyarakat untuk mencapai tujuan penghidupan mereka.Sumber daya sosial umumnya bersifat intangible tidak mudah untuk diukur, namun memiliki manfaat bagi masyarakat (DFID 2001). Modal sosial terdiri dari unsur organisasi masyarakat, partisipasi, gotong royong, hubungan kekerabatan, dan jaringan sosial (Tabel 5).

Bagian tengah memiliki nilai aset sosial paling tinggi $(5,83)$, menyusul bagian bawah $(4,63)$, dan bagian atas $(3,91)$. Dari sisi organisasi kemasyarakatan, seluruh responden $(100 \%)$ di bagian tengah ikut dalam organisasi sosial. Namun demikian, hanya sebanyak $65,71 \%$ responden bagian atas yang ikut organisasi. Alasan responden bagian atas ikut berorganisasi antara lain untuk kemasyarakatan, mendapat banyak teman, memperoleh informasi penting, dan bukti kekompakan warga. Alasan responden Sub DAS bagian bawah tidak ikut dalam organisasi karena faktor usia yang sudah tua dan kesibukan pekerjaan. 
Tabel 5. Nilai Variabel Penyusun Modal Sosial

\begin{tabular}{lccc}
\hline \multirow{2}{*}{ Variabel } & \multicolumn{3}{c}{ Nilai skala } \\
\cline { 2 - 4 } & Atas & Tengah & Bawah \\
\hline Organisasi masyarakat & 3,22 & 6,99 & 4,01 \\
Partisipasi & 4,59 & 6,29 & 4,73 \\
Gotong royong & 3,60 & 5,00 & 4,78 \\
Hubungan kekerabatan & 4,93 & 7,27 & 6,21 \\
Jaringan sosial & 3,21 & 3,59 & 3,43 \\
Total nilai & 19,56 & 29,14 & 23,16 \\
Rata-rata & $\mathbf{3 , 9 1}$ & $\mathbf{5 , 8 3}$ & $\mathbf{4 , 6 3}$ \\
\hline Sumber: Data Primer, 2016 & & &
\end{tabular}

Dilihat dari jenis organisasi yang paling banyak dikuti, organisasi kelompok tani adalah jenis organisasi yang paling banyak diikuti dan disusul oleh organisasi KTNA (Kelompok Tani Nelayan Andalan). Beberapa manfaat bergabung dalam kelompok tani, seperti untuk sarana akses terhadap segala bentuk bantuan terkait usaha tani. Hasil survei terhadap responden di 3 bagian sub DAS seperti dalam Tabel 6 menunjukkan persentase responden yang memperoleh manfaat dari masing-masing organisasi/ kegiatan yang difasilitasi oleh kelompok tani.

Tabel 6. Kegiatan yang Difasilitasi oleh Kelompok Tani

\begin{tabular}{lccc}
\hline \multirow{2}{*}{ Fasilitasi Bagi Peserta Kelompok Tani } & \multicolumn{3}{c}{ Responden yang Memperoleh Manfaat } \\
\cline { 2 - 4 } & Atas & Tengah & Bawah \\
\hline Meminjam/mendapatkan modal usaha tani & $22,86 \%$ & $68,75 \%$ & $22,86 \%$ \\
Mendapatkan benih & $80,00 \%$ & $100,00 \%$ & $60,00 \%$ \\
Mendapatkan pupuk bersubsidi & $54,29 \%$ & $93,75 \%$ & $68,57 \%$ \\
Mendapat fasilitas sewa alat mesin pertanian & $20,00 \%$ & $78,13 \%$ & $42,86 \%$ \\
Mendapatkan penyuluhan (ceramah, diskusi, praktek, & $68,57 \%$ & $87,50 \%$ & $51,43 \%$ \\
demplot, dll) & $0,00 \%$ & $28,13 \%$ & $34,29 \%$ \\
Melaksanakan pola tanam serempak & $0,00 \%$ & $100,00 \%$ & $40,00 \%$ \\
Memelihara irigasi & $2,86 \%$ & $93,75 \%$ & $37,14 \%$ \\
Mendapat giliran irigasi & $34,29 \%$ & $62,50 \%$ & $20,00 \%$ \\
Mendapatkan pelatihan & $14,29 \%$ & $62,50 \%$ & $20,00 \%$ \\
Bantuan dana bergulir & & & \\
\hline
\end{tabular}

Sumber: Data Primer, 2016

Bentuk partisipasi masyarakat paling banyak adalah berbagi pengalaman dan mengajukan pertanyaan-pertanyaan.Jadwal pertemuan kelompok secara rutin dijadwalkan olehkelompok di bagian tengah dan bagian atas yaitu selapan hari sekali (35 hari sekali). Pada bagian bawah, jadwal pertemuan tidak dilakukan teratur, dan biasanya digabung dengan pertemuan Rukun Tetangga. Alasan tidak teraturnya jadwal pertemuan kelompok adalah kesibukan warga untuk mencukupi kebutuhan ekonomi keluarga mereka sehingga menghadiri pertemuan mengurangi waktu bekerja.

Pada daerah pedesaan yang memiliki hubungan kekerabatan tinggi, bantuan sanak saudara, tetangga dan teman dapat diandalkan saat terjadi krisis rumah tangga petani. 
Keterlibatan masyarakat dalam aksi-aksi gotong royong, seperti pemeliharaan saluran irigasi, mata air, geropyokan tikus, dan pengaturan air merupakan contoh keterlibatan dalam bentuk tenaga dan paling banyak ditemukan dan disusul oleh keterlibatan dalam bentuk pemberian bantuan iuran (uang), sedangkan kegiatan sedekah bumi pertisipasi masyarakat diujudkan dalam bentuk tenaga dan uang. Meskipun demikian, masih ada responden yang tidak ikut dalam gotong royong.

Jaringan sosial yang juga digunakan untuk menilai modal sosial dalam penelitian ini adalah handphone (HP). HP tidak hanya bermanfaat sebagai alat berkomunikasi antar individu, namun dapat dimanfaatkan untuk tujuan meningkatkan penghidupan. Pengguna HP paling banyak adalah responden di Sub DAS bagian tengah $(78,13 \%)$ sedangkan sub DAS bagian atas dan bawah masing-masing 60\%. Namun demikian, penduduk berusia tua tidak menggunakan HP. Biasanya mereka mengandalkan anak-anaknya untuk membantu berkomunikasi dengan dunia luar. Penggunaan komputer/ laptop/ HP yang tersambung dengan internet sudah mulai dilakukan, responden di sub DAS bagian bawah paling banyak $(45,71 \%)$ mengakses internet dan responden di sub DAS bagian atas paling rendah mengakses (34,29\%). Hanya sekitar $12,75 \%$ responden di Sub DAS Pusur yang terhubung dengan jejaring sosial/grup seperti WhatsApp, Line, Facebook, dan Twitter. Dari seluruh responden hanya $18,53 \%$ responden yang menyatakan memperoleh manfaat dari jejaring sosial tersebut untuk meningkatkan penghidupan. Di era teknologi seperti sekarang, alat komunikasi dan jaringan sosial dapat membantu petani mendapatkan informasi terkini tentang harga komoditas, pemasaran, cara produksi, teknologi tepat guna, dan lain-lain.

\section{Modal Finansial}

Modal finansial adalah sumber-sumber keuangan yang dapat digunakan dan dimanfaatkan masyarakat dalam mencapai tujuan penghidupan mereka, yaitu meliputi cadangan atau persediaan baik milik sendiri ataupun lembaga keuangan, serta berupa aliran dana teratur (DFID, 2001). Modal finansial meliputi penghasilan, pengeluaran, tabungan, hutang piutang, dan bantuan (Tabel 7).

Tabel 7. Nilai Variabel Penyusun Modal Finansial

\begin{tabular}{lccc}
\hline \multirow{2}{*}{\multicolumn{1}{c}{ Variabel }} & \multicolumn{3}{c}{ Nilai skala } \\
\cline { 2 - 4 } & Atas & Tengah & Bawah \\
\hline Penghasilan & 3,06 & 2,98 & 2,65 \\
Pengeluaran & 5,21 & 3,48 & 4,29 \\
Tabungan & 3,68 & 2,05 & 0,92 \\
Hutang-piutang & 4,02 & 2,52 & 2,79 \\
Bantuan & 2,86 & 6,56 & 1,43 \\
Total nilai & 18,83 & 17,58 & 12,08 \\
Rata-rata & $\mathbf{3 , 7 7}$ & $\mathbf{3 , 5 2}$ & $\mathbf{2 , 4 2}$ \\
\hline
\end{tabular}

Sumber: Data Primer, 2016

Dari segi aset finansial, responden tertinggi ada di bagian atas $(3,77)$, menyusul responden bagian tengah $(3,52)$, dan terendah responden bagian bawah $(2,42)$. Sumber keuangan utama bagi responden adalah dari hasil usaha yang dapat berupa agroforestri, pemanfaatan lahan pekarangan, warung, dan hasil kerajinan, selanjutnya berasal dari upah. Rumah tangga di bagian atas mengusahakan lahan tadah hujan mereka dengan tanaman keras dan tanaman bawah tegakan serta rumput pakan ternak (sistem agroforestri). Dengan 
sistem agroforestri dan usaha ternak dengan dominasi ternak sapi perah dan sebagian kambing, responden di bagian atas memiliki penghasilan tetap yaitu setiap hari dari hasil penjualan susu sapi perah dan setiap 5 (lima) hari sekali dari hasil penjualan pepaya. Tanaman keras terutama sengon merupakan tabungan yang bisa dipanen setelah 5 (lima) tahunan. Lahan pekarangan terutama di bagian atas dimanfaatkan dengan sangat baik untuk tanaman sayuran dan buah sehingga dapat menambah gizi dan mengurangi pengeluaran keluarga. Selain itu, lahan pekarangan juga banyak dimanfaatkan untuk kandang ternak dan ditemui juga kolam ikan tadah hujan. Kotoran ternak sapi selain bisa digunakan untuk pupuk kandang, sudah banyak dikembangkan pemanfaatannya di bagian atas Sub DAS Pusur untuk menghasilkan energi terbarukan biogas dengan hasil sampingan berupa pupuk organik cair maupun padat. Pengembangan biogas dari limbah kotoran sapi ini merupakan salah satu alternatif pemecahan dalam rangka mencari sumber energi alternatif sekaligus sebagai upaya konservasi, membantu mengatasi pencemaran udara (bau tidak sedap), pencemaran tanah dan air dengan adanya leaching dan eutrofikasi yang menyebabkan terganggunya biota sungai, serta pencemaran biologis (penyakit) melalui vektor lalat (Mulyatun, 2016). Teknologi tepat guna ini secara ekonomis mampu mengurangi pengeluaran rumah tangga untuk pembelian gas elpiji, pupuk organik serta penggunaan kayu bakar.

Namun, ada alokasi dana lain yang harus dikeluarkan oleh responden di bagian atas yaitu untuk pembayaran pemakaian air kebutuhan domestik yang jumlahnya cukup besar. Harga pemakaian air tanah adalah Rp. 6.000,00 per $\mathrm{m}^{3}$. Pembayaran air biasanya lebih banyak saat kemarau, terutama untuk kebutuhan makan minum ternak. Selain dari air tanah, kebutuhan air untuk ternak juga berasal dari pemanenan air hujan skala rumah tangga dengan menggunakan tandon atau bak dan dapat digunakan saat musim kemarau. Hasil survei menyebutkan, sebanyak $82,86 \%$ responden di bagian atas pengeluaran untuk pemenuhan kebutuhan air domestik kurang dari Rp.100.000,00 per bulan dan 17,14\% responden harus mengeluarkan anggaran Rp. 100.000,00 s.d 500.000,00 per bulan. Responden dengan jumlah ternak banyak membutuhkan air dalam jumlah banyak, rata-rata 1 (satu) ekor sapi membutuhkan air sekitar 20-30 liter/hari untuk campuran makanannya. Responden di bagian tengah harus mengeluarkan dana untuk pembelian air sebesar Rp. $3.000,00 / \mathrm{m}^{3}$ apabila menggunakan sambungan air dari PAMSIMAS. Namun mereka masih mempunyai sumur untuk kebutuhan MCK. Responden bagian bawah 100\% menggunakan air tanah dari sumur untuk kebutuhan domestik rumah tangga.

Pendapatan keluarga di bagian tengah dan bawah, terbantu dari peran istri atau wanita menekuni home industry. Di bagian tengah kegiatan industri rumah tangga sudah sangat dikenal. Adapun kegiatan industri rumah tangga berupa pembuatan souvenir berbahan baku tanduk, kain perca, kulit binatang, sedangkan di bagian bawah para istri atau wanita berperan dalam industri rumah tangga payet dan bordir. Sebagian besar responden di bagian bawah bukan lagi petani pemilik, mereka sudah banyak yang beralih dari pemilik menjadi buruh tani dengan sistem bagi hasil (maron, mprapat, ataupun pekerja upah di sawah), peran wanita muda (usia $<30$ tahun) bisa membantu bekerja di pabrik sedangkan wanita lebih tua (usia > 30 tahun) membantu ekonomi dengan bekerja di sawah. Sebanyak $91,43 \%$ responden di bagian atas, $71,88 \%$ di bagian tengah, dan $45,71 \%$ di bagian bawah menyatakan pendapatan mereka cukup untuk memenuhi kebutuhan hidup.

Pada bagian atas, sebanyak 100\% responden memiliki tabungan dalam bentuk tanaman keras/kayu dan 94,29\% responden menganggaphewan ternakmerupakan wujud tabungan yang liquid (sewaktu-waktu butuh uang bisa dijual). Tanaman keras merupakan tabungan jangka menengah, umur lima tahun baru bisa dipanen. RT di bagian tengah lebih suka menabung dalam bentuk emas/perhiasan (53,13\%) dan menabung di bank (31,25\%) juga di rumah $(31,25 \%)$. RT di bagian bawah lebih memilihmenyimpan uang di bank $(31,43 \%)$, sebagian yang lain menyimpan dalam bentuk emas/perhiasan dan hewan ternak 
$(11,43 \%)$. Mengenai peminjaman uang ke pihak bank atau penyedia jasa, sebagian besar responden menyatakan tidak pernah meminjam karena alasan bunga pinjaman yang tinggi dan memberatkan. Bantuan keuangan yang selama ini diterima responden berasal terutama dari kiriman anak dan dari bantuan pemerintah.

\section{Modal Fisik}

Modal fisik adalah prasarana dasar dan fasilitas lain yang dibangun untuk mendukung proses penghidupan masyarakat. Prasarana yang dimaksud meliputi pengembangan lingkungan fisik yang membantu masyarakat dalam melaksanakan tugas kehidupan lebih produktif.Prasarana umumnya merupakan fasilitas umum yang digunakan tanpa dipungut biaya langsung (DFID, 2001). Modal fisik meliputi sarana dan prasarana, peralatan kerja/produksi, dan teknologi (Tabel 8). Bagian atas memiliki nilai modal fisik paling tinggi sebesar 7,56, bagian tengah sebesar 6,61, dan yang terendah adalah bagian bawah sebesar 5,90 . Rumah tangga di bagian atas memiliki modal fisik paling tinggi karena $71,43 \%$ responden menggunakan sepeda motor untuk ke sawah, sebesar $80 \%$ responden menyatakan lahan produktifnya bisa dijangkau mobil, sebesar $97,14 \%$ responden menempati rumah milik sendiri dan kondisinya bagus, dan sebesar 97,14 \% responden menyatakan jarak rumah ke pasar kurang dari dua $\mathrm{km}$.

Responden bagian bawah memiliki modal fisik paling rendah karena hanya sebesar $40,00 \%$ responden yang menggunakan sepeda motor untuk ke sawah, sebesar $22,86 \%$ lahan produktif yang bisa dijangkau mobil, sebesar $42,86 \%$ responden masih menempati rumah tumpangan dan menyewa dengan $62,86 \%$ kondisi rumah rusak sampai kurang baik. Selain itu, sebanyak 35,29\% responden menyatakan lahannya tidak terjangkau saluran irigasi sehingga membutuhkan pompa air diesel untuk irigasi suplementer yang airnya berasal dari sumur pantek, Sungai Pusur, atau Bengawan Solo. Jumlah sumur pantek yang dibuat sebelum tahun 2000 dibandingkan setelah tahun 2000 meningkat 2 (dua) kali lipat.

Tabel 8. Nilai Variabel Penyusun Modal Fisik

\begin{tabular}{lccc}
\hline \multirow{2}{*}{\multicolumn{1}{c}{ Variabel }} & \multicolumn{3}{c}{ Nilai skala } \\
\cline { 2 - 4 } & Atas & Tengah & Bawah \\
\hline Sarana & 9,43 & 8,52 & 6,96 \\
Prasarana & 9,29 & 7,81 & 5,64 \\
peralatan kerja & 2,51 & 3,38 & 2,57 \\
Aksesibilitas & 9,00 & 6,72 & 8,43 \\
Total nilai & 30,23 & 26,42 & 23,61 \\
Rata-rata & $\mathbf{7 , 5 6}$ & $\mathbf{6 , 6 1}$ & $\mathbf{5 , 9 0}$ \\
\hline Sumber: Data Primer, 2016 & & &
\end{tabular}

\section{Strategi Penghidupan Masyarakat}

Scoones (1998) mengelompokkan strategi penghidupan menjadi 3 (tiga), yaitu:

- Intensifikasi dan ekstensifikasi, yaitu tetap bertahan pada mata pencaharian semula. Namun demikian, intensifikasi memberikan penekanan pada usaha peningkatan hasil produksi per satuan luas melalui penanaman modal atau peningkatan input tenaga kerja, sedangkan ekstensifikasi mengupayakan lebih banyak tanah untuk ditanami.

- Diversifikasi, yaitu mencari alternatif lain dari kegiatan off-farm atau non-farm sebagai sarana pemenuhan kebutuhan ketika mata pencaharian lama dirasa tidak memungkinkan. 
- Migrasi, yaitu mencari penghidupan di tempat lain baik sementara atau permanen serta berganti pekerjaan.

Berdasarkan hasil penelitian, kegiatan strategi penghidupan berkelanjutan masyarakat adalah:

- $\quad$ Strategi intensifikasi dan ekstensifikasi

Strategi intensifikasi dan ekstensifikasi meliputi pemanfaatan lahan pekarangan, pemanfaatan lahan pertanian, pemanfaatan lahan kosong, dan penambahan lahan garapan (Tabel 9).

Tabel 9. Kegiatan Strategi Intensifikasi dan Ekstensifikasi

\begin{tabular}{lccc}
\hline \multicolumn{1}{c}{ Kegiatan } & Atas & Tengah & Bawah \\
\hline Pemanfaatan lahan pekarangan & $80,00 \%$ & $15,63 \%$ & $14,29 \%$ \\
Pemanfaatan lahan pertanian & $100,00 \%$ & $6,25 \%$ & $0,00 \%$ \\
Pemanfaatan lahan kosong & $25,71 \%$ & $31,25 \%$ & $2,86 \%$ \\
Penambahan lahan garapan & $0,00 \%$ & $6,25 \%$ & $2,86 \%$ \\
\hline Sumber: Data Primer, 2016 & & &
\end{tabular}

Pemanfaatan lahan pekarangan paling banyak dilakukan oleh responden di bagian atas $(80,00 \%)$. Selanjutnya oleh responden bagian tengah $(15,63 \%)$ dan terakhir oleh bagian bawah (14,29\%). Di bagian tengah dan bawah, umumnya lahan pekarangan ditanami tanaman buah-buahan. Pada bagian atas, tanaman buah $(62,50 \%)$ (dengan durian sebagai komoditas unggulan), sedangkan pada bagian tengah sebesar $9,38 \%$ dan bagian bawah sebesar $12,50 \%$. Selain tanaman buah, sebanyak $12,50 \%$ responden bagian atas menanam tanaman keras di pekarangan seperti tanaman sengon dan kelapa, serta pemanfaatan lahan pekarangan untuk kegiatan lain mencapai $75,00 \%$. Pemanfaatan lainnya ini umumnya dimanfaatkan responden untuk pembuatan bibit, tanaman empon-empon, dan kandang ternak. Untuk bagian tengah dan bawah, pemanfaatan lahan pekarangan tidak seintensif pada bagian atas.

Strategi intensifikasi dan ekstensifikasi pada lahan pertanian memiliki perbedaan antara daerah atas dibandingkan daerah tengah dan bawah. Pada daerah atas, strategi intensifikasi lahan pertanian dilakukan dengan cara mengusahakan lebih dari satu jenis tanaman pada satu lahan pertanian pada waktu yang bersamaan. Hal ini dilakukan oleh semua responden bagian atas dan mampu memberi hasil terus menerus sepanjang tahun.Sepanjang pinggir petak lahan umumnya ditanami tanaman kayu-kayuan. Tanaman sengon menjadi komoditas kayu andalan. Diantara tanaman tanaman sengon ditanami rumput pakan ternak. Fungsi sengon selain sebagai pembatas dengan lahan pertanian sebelahnya juga berfungsi sebagai tabungan yang dapat dipanen setelah berumur lebih dari 5 (lima) tahun dan sudah memiliki pasar yang jelas. Selain itu sengon disukai masyarakat karena mampu bersimbiosis dengan tanaman bawah tegakan.

Pada tengah lahan pertanian, ditanami berbagai macam tanaman semusim yang memiliki masa panen berbeda. Sebagai contohnya adalah kombinasi antara padi, cabai, pepaya dan ubi kayu. Masa panen padi sekitar 90-100 hari dan setelah itu dilanjutkan dengan panen cabai sampai tanaman cabai berumur 6-7 bulan.Setelah cabai tidak lagi produktif, tanaman ubi kayu dapat mulai dipanen. Contoh lainnya adalah penanaman sengon yang dikombinasikan dengan pepaya. Pepaya bisa dipanen setiap 5 (lima) hari dan dapat bertahan sampai umur tanaman 2 (dua) tahun. Sistem penggunaan lahan (usaha tani) yang mengkombinasikan pepohonan dengan tanaman pertanian untuk meningkatkan keuntungan, baik secara ekonomis maupun lingkungan seperti yang dilakukan responden 
bagian atas tersebut disebut agroforestry (World Agroforestry Center, 2004). Strategi ini dimaksudkan untuk mengantisipasi ketersediaan air yang ada hanya pada musim hujan saja karena tidak tersedia air dari irigasi.

Pada bagian tengah dan bawah, strategi intensifikasi lebih kearah mengoptimalkan hasil sawah berupa padi dengan kegiatan pancausaha tani. Kegiatan panca usaha tani, terdiri dari kegiatan (1) pengolahan tanah yang baik, (2) pemilihan bibit unggul, (3) pengairan/irigasi, (4) pemupukan yang tepat, dan (5) pembasmian hama penyakit (Surya, Sardi, \& Aprolita, 2015). Umumnya di lahan sawah, padi merupakan tanaman tunggal. Penanaman padi pada bagian tengah dilakukan sepanjang tahun, atau sebanyak 3 (tiga) kali musim tanam tanpa diselingi tanaman lain ataupun dibiarkan bero/istirahat. Hal ini telah menjadi bagian dari budaya bertani pada daerah tersebut.Sisi baik dari budaya bertani tersebut adalah daerah tengah dikenal sebagai lumbung padi untuk daerah Klaten dan sekitarnya karena memberikan hasil padi yang melimpah. Sisi kurang baiknya antara lain sulitnya memperkenalkan hal baru seperti program pemerintah "jajar legowo" dan sistem pertanian padi organik. Pemanfatan lahan kosongdi bagian atas dilakukan sebanyak 25,71\% responden, bagian tengah sebanyak $31,25 \%$ responden, dan bagian bawah hanya $2,86 \%$ responden dan umumnya berupa tanaman buah.

Strategi berupa penambahan lahan garapan tidak dilakukan di bagian atas, dan hanya dilakukan sedikit responden dibagian tengah $(6,25 \%)$ dan bagian bawah $(2,86 \%)$. Hal ini dikarenakan pada bagian atas lahan digarap sendiri oleh pemilik, kecuali lahan bengkok yang menjadi hak garap perangkat desa. Hal ini dikarenakan luasnya lahan bengkok, perangkat tidak mampu mengerjakan lahan sendirian, dan sebagian ada yang disewakan atau digarapkan orang lain dengan sistem bagi hasil.

- $\quad$ Strategi diversifikasi

Kegiatan ekonomi perdesaan tidak semata-mata melandaskan diri pada sektor pertanian. Bermacam-macam aktivitas dan usaha lainnya turut mempengaruhi ekonomi perdesaan. Pemikiran ini berdasarkan pada konsep diversifikasi penghidupan sebagai strategi bertahan hidup rumah tangga perdesaan di negara-negara berkembang (Ellis, 2000). Pertanian memang masih dianggap penting bagi sebagian orang desa,tetapi masyarakat tetap berusaha mencari kesempatan untuk meningkatkan pendapatan mereka. Asumsi penganekaragaman penghidupan didasari kerangka aktivitas orang miskin di perdesaan yang ditentukan oleh penguasaan aset-aset meliputi sosial, manusia, keuangan, lingkungan alam, dan modal fisik. Strategi ini meliputi kegiatan pertanian diluar bercocok tanam, sektor perdagangan, sektor jasa, penghasilan dari modal, penambahan jam kerja, dan pengolahan dan pemasaran hasil pertanian (Tabel 10).

Tabel 10. Kegiatan Strategi Diversifikasi

\begin{tabular}{lrrr}
\hline \multicolumn{1}{c}{ Kegiatan } & \multicolumn{1}{c}{ Atas } & Tengah & Bawah \\
\hline Pertanian diluar bercocok tanam & $85,71 \%$ & $12,50 \%$ & $22,86 \%$ \\
Sektor perdagangan & $34,29 \%$ & $21,88 \%$ & $14,29 \%$ \\
Sektor Jasa & $8,57 \%$ & $37,50 \%$ & $31,43 \%$ \\
Penghasilan dari modal & $0,00 \%$ & $0,00 \%$ & $0,00 \%$ \\
Pengolahan dan pemasaran hasil pertanian & $74,29 \%$ & $65,63 \%$ & $51,43 \%$ \\
\hline Sumber: Data primer, 2016 & & &
\end{tabular}

Strategi diversifikasi berupa kegiatan pertanian diluar bercocok tanam, paling banyak dilakukan oleh responden di bagian atas (85,71\%), sebanyak $22,86 \%$ responden bagian 
bawah sebesar, dan sedikit responden di bagian tengah (12,50\%). Kegiatan yang paling banyak dilakukan adalah peternakan. Sebanyak $82,86 \%$ responden bagian atas memelihara ternak dan umumnya ternak sapi perah. Sapi perah ini dapat menghasilkan susu setiap hari yang diperah 2 (dua) kali, yaitu pada pagi hari sekitar pukul 08.00 WIB dan siang hari sekitar pukul 14.00 WIB dengan total produksi tiap sapi sebesar 15-25 liter per hari. Pada sore hari, hasil susu disetor kepada pedagang pengumpul atau disetor melalui koperasi. Sapi perah dipilih karena selain menghasilkan susu juga dianggap sebagai tabungan yang dapat dijual setiap saat apabila membutuhkan uang. Disamping itu, iklim daerah atas dan ketersediaan pakan ternak mendukung untuk pemeliharaan sapi perah. Keterbatasan ketersediaan air pada daerah atas karena air untuk kebutuhan domestik harus diperoleh dari membeli melalui air pipa maupun tangki atau dengan menampung air hujan pada bak penampungan pada musim penghujan menjadi kendala.

Diversifikasi melalui sektor perdagangan, dilakukan oleh $34,29 \%$ responden bagian atas,sebanyak $21,88 \%$ responden bagian tengah, dan oleh $14,29 \%$ responden bagian bawah. Diversifikasi pada sektor perdagangan tidak ada kegiatan yang dominan.Kegiatan ini terdiri dari membuka toko kelontong atau "mracangan", warung makan, berdagang di pasar, maupun kegiatan perdagangan lainnya.

Kegiatan diversifikasi melalui sektor jasa dilakukan oleh 8,57\% responden bagian atas, bagian tengah sebesar 37,50\% responden, dan bagian bawah sebesar 31,43\% responden. Kegiatan didominasi sebagai karyawan atau buruh terutama untuk bagian tengah $(28,13 \%)$ dan bawah $(17,14 \%)$. Pemilihan sebagai karyawan atau sebagai buruh merupakan pilihan yang mudah dan tepat karena pada daerah tengah dan bawah relatif dekat dengan kegiatan industri atau pertokoan yang membutuhkan banyak tenaga kerja.

Strategi penghidupan dari penghasilan yang berasal dari kepemilikan harta, misalnya dari deposito, deviden, Sisa Hasil Usaha (SHU) koperasi, asuransi, persewaan, maupun lainnya, baik responden bagian atas, tengah, maupun bawah tidak ada yang melakukan. Penghasilan yang berasal dari kepemilikan harta kemungkinan belum terlalu dikenal oleh responden. Responden lebih memilih kegiatan yang bersifat nyata, seperti bertani ataupun menjadi buruh.

Peningkatan pendapatan melalui penambahan jam kerja, dilakukan oleh sebagian responden terutama oleh responden bagian bawah sebanyak $25,71 \%$ responden. Untuk responden bagian tengah dan bawah tidak banyak yang melakukannya, hanya 5,71\% responden di bagian atas dan $12,50 \%$ responden di bagian tengah. Penambahan jam kerja tersebut terutama pada sektor jasa. Pemilihan penambahan pekerjaan di sektor jasa lebih dipilih karena sektor ini hanya membutuhkan tenaga, ketrampilan, dan waktu luang.

Kegiatan pengolahan dan pemasaran hasil pertanian dikelompokkan menjadi (1) diolah untuk dikonsumsi sendiri, (2) diolah dan dipasarkan, serta (3) diolah, dikemas, dipasarkan. Responden yang mengolah hasil pertanian untuk dikonsumsi sendiri dilakukan paling banyak oleh responden di bagian atas $(68,57)$, sebanyak $45,71 \%$ responden bagian bawah, dan $37,50 \%$ responden bagian tengah. Kegiatan ini misalnya padi diolah menjadi beras untuk konsumsi sendiri, ketela dan rumput untuk pakan ternak, bambu atau kayu dari kebun untuk kebutuhan bahan bangunan milik sendiri.

Kegiatan pengolahan dan pemasaran hasil pertanianuntuk dipasarkan belum banyak dilakukan, hanya dilakukan $11,43 \%$ responden di bagian atas, $15,63 \%$ responden di bagian tengah, dan $25,71 \%$ di bagian bawah. Pemasaran hasil pertanian umumnya dilakukan responden langsung kepada pedagang/tengkulak. Pemasaran langsung kepada pedagang/ tengkulak dilakukan oleh $88,57 \%$ responden di bagian atas, $93,75 \%$ responden di bagian tengah, dan $82,86 \%$ responden di bagian bawah. Penjualan langsung kepada pedagang/ tengkulak dan bukan kepada konsumen disebabkan responden atau petani tidak memiliki akses langsung terhadap pasar. Responden lebih berfokus kepada cara untuk meningkatkan produksi lahannya. Selain itu, dengan menjual langsung kepada pedagang/ tengkulak akan 
menjamin barang produksi atau hasil pertaniannya laku terjual. Kerugian apabila dijual kepada pedagang/ tengkulak antara lain adalah posisi tawar terhadap harga komoditas menjadi lemah.

\section{- $\quad$ Strategi migrasi}

Strategi migrasi meliputi migrasi permanen dan mobilitas sirkuler/ komuter.Migrasi permanen adalah pindah tempat tinggal secara permanen. Migrasi ini paling tinggi dilakukan oleh anggota keluarga responden di bagian tengah $(56,25 \%)$ dan paling sedikit dilakukan oleh anggota keluarga responden bagian bawah (40,00\%)dengan alasan menikah. Migrasi permanen yang dilakukan untuk alasan pekerjaan lokasi pindahnya biasanya ke luar kabupaten, paling banyak dilakukan oleh responden di bagian atas $(31,43 \%)$, responden di bagian tengah $(31,25 \%)$ dan responden di bagian bawah $(14,29 \%)$. Pelaku migrasi paling banyak adalah kepala keluarga (KK) dan anak-anak mereka.

Tabel 11. Kegiatan Strategi Migrasi

\begin{tabular}{lccc}
\hline \multicolumn{1}{c}{ Kegiatan } & Atas & Tengah & Bawah \\
\hline Migrasi permanen & $45,71 \%$ & $56,25 \%$ & $40,00 \%$ \\
Mobilitas sirkuler/komuter & $20,00 \%$ & $18,75 \%$ & $37,14 \%$ \\
\hline Sumber: Data Primer, 2016 & & &
\end{tabular}

Selain migrasi permanen, dijumpai pula mobilitas sirkuler/ komuter atau lebih dikenal dengan istilah "nglajo". Kegiatan "nglajo" dilakukan setiap hari. Mobilitas sirkuler/ komuter adalah aspek yang dinamis untuk mencari lapangan kerja. Bekerja dengan cara menglajo (perjalanan lebih dari 30 menit atau lebih dari $15 \mathrm{~km}$ ) tidak banyak dilakukan responden dan anggota keluarganya. Adapun responden yang biasa melakukan "nglajo" adalah anak-anak para responden, pegawai, buruh pabrik, dan pekerja bangunan karena jarak lokasi ke tempat bekerja atau sekolah yang masih terjangkau. Di sisi lain, "nglajo" juga lebih hemat biaya karena tidak ada biaya untuk indekost atau sewa rumah. Responden dan anggota rumah tangga di bagian atas yang melakukan kegiatan "nglajo" biasanya bekerja di Kota Boyolali atau Klaten. Sementara itu, untuk bagian bawah, "nglajo" ke Kota Sukoharjo atau Solo.

Selain migrasi yang bersifat pindah lokasi, terdapat juga migrasi alih pekerjaan atau berpindah dari satu lapangan usaha ke lapangan usaha lainnya. Pekerjaan yang dipilih biasanya adalah pekerjaan yang dapat memberikan upah rutin, baik itu sebagai buruh pabrik, karyawan toko, pegawai negeri sipil, dan sebagainya. Pekerjaan dengan upah rutin dipilih karena lebih menjamin keberlanjutan hidup. Sementara itu, dari sisi industri, perempuan usia muda menjadi pilihan bagi pabrik dengan alasan produktivitas lebih tinggi dibandingkan perempuan usia tua, dan tidak banyak menuntut kenaikan gaji/ kesejahteraan, serta tidak sering pindah-pindah kerja.

Munculnya pilihan pekerjaan non-pertanian merupakan dampak antara kesempatan kerja dan pendapatan, antara lain karena a) tidak cukupnya pendapatan di sektor pertanian, b) pekerjaan dan pendapatan usaha tani umumnya bersifat musiman sehingga perlu menunggu waktu relatif lama mendapatkan hasil/ pendapatannya, c) usaha tani banyak mengandung resiko dan ketidakpastian, dan d) kesempatan kerja dan pendapatan nonpertanian menjadi penting untuk kelompok rumah tangga buruh tani dan petani gurem, sebagai kelompok termiskin (Mukbar, 2009).

Migrasi dari pekerjaan pertanian ke non-pertanian tidak banyak dilakukan responden. Migrasi ini dilakukan oleh 18,75\% responden bagian tengah, $11,43 \%$ responden di bagian bawah, dan tidak ada sama sekali responden di bagian atas. Alasan melakukan migrasi alih 
pekerjaan adalah karena pekerjaan lama hasilnya kurang mencukupi atau tidak bisa berkembang. Adapun pelakunya sebagian besar adalah anak dari responden yang umumnya bekerja sebagai buruh pabrik. Untuk lebih jelasnya, strategi yang dipilih oleh responden di daerah penelitian dapat dilihat seperti dalam Gambar 2.

Berbagai strategi penghidupan yang dilakukan oleh responden berpengaruh terhadap peningkatan penghidupan dan keberlanjutan lingkungan terutama dalam konteks pengelolaan DAS. Pengaruh utama disajikan dalam Tabel 12. Berdasarkan pengaruh tersebut, upaya peningkatan pengelolaan agroforestri di bagian atas harus mulai dilakukan. Sementara itu, untuk bagian tengah dan bawah mulai beralih kepada pertanian yang lebih ramah lingkungan namun memiliki produktivitas yang tinggi.

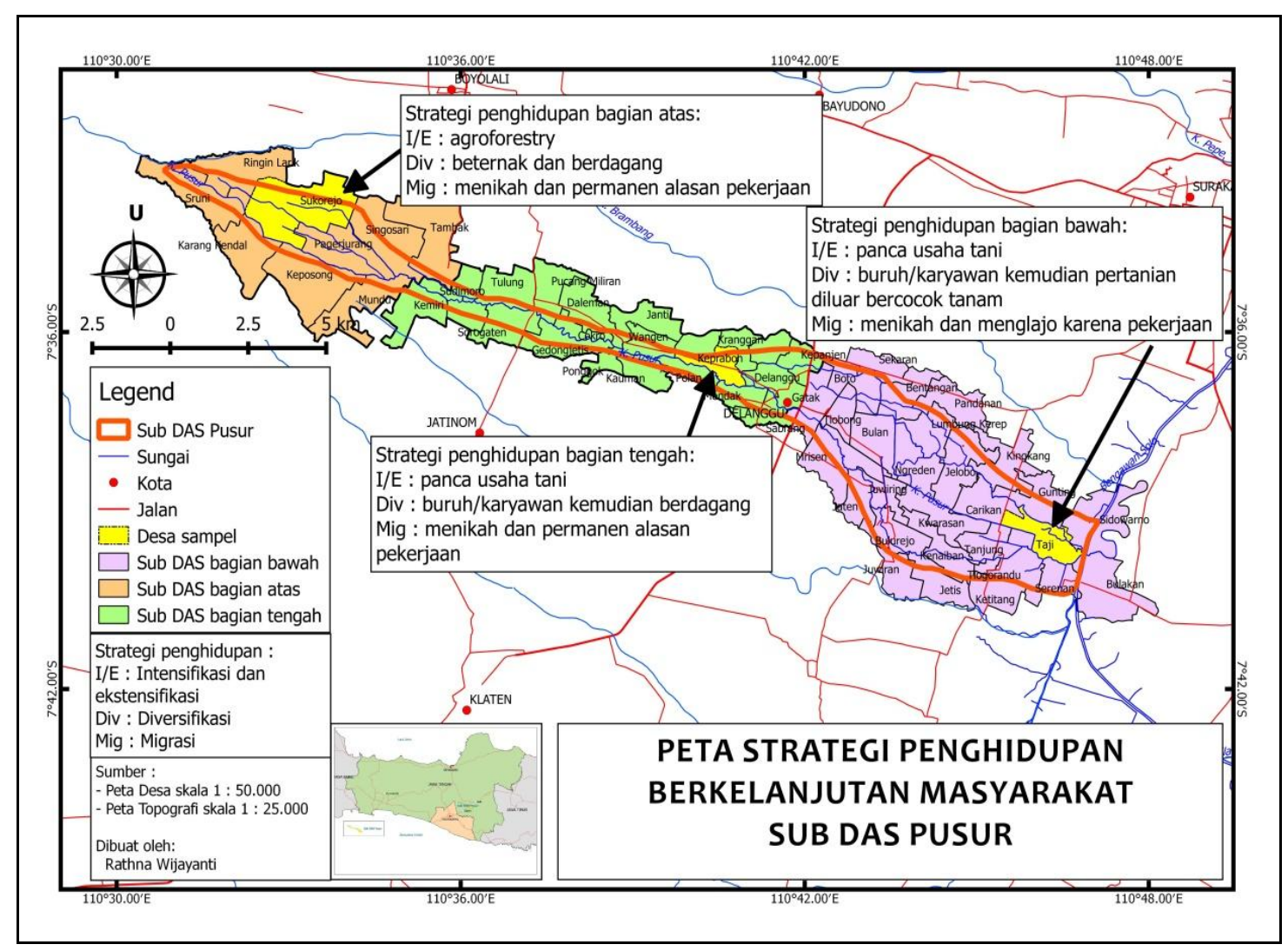

Gambar 2. Peta Strategi Penghidupan Berkelanjutan

Tabel 12. Pengaruh Strategi Penghidupan terhadap Peningkatan Penghidupan dan Keberlanjutan Lingkungan

\begin{tabular}{llrlrl}
\hline Pengaruh & \multicolumn{2}{c}{ Atas } & Tengah & Bawah \\
\hline Terhadap & Dengan & strategi & Sektor pertaniansawah & Peningkatan penghidupan \\
peningkatan & intensifikasi/ & & masih sebagai penopang & dengan & diversifikasi \\
penghidupan & ekstensifikasi pertanian & utama penghidupan namun & sumber penghasilan pada \\
& maupun diversifikasi & penghasilan cenderung & sektor jasa dan migrasi \\
& pertanian, mempunyai & tetap karena produktivitas & sirkuler/"nglajo". Sektor \\
& lebih banyak sumber & sawah tetap. Penghasilan ini semakin lama akan \\
& penghasilan dan tabungan & akan meningkat bila ada menggeser & sektor \\
& untuk penghidupan dari & inovasi & peningkatan pertanian karena modal \\
\hline
\end{tabular}




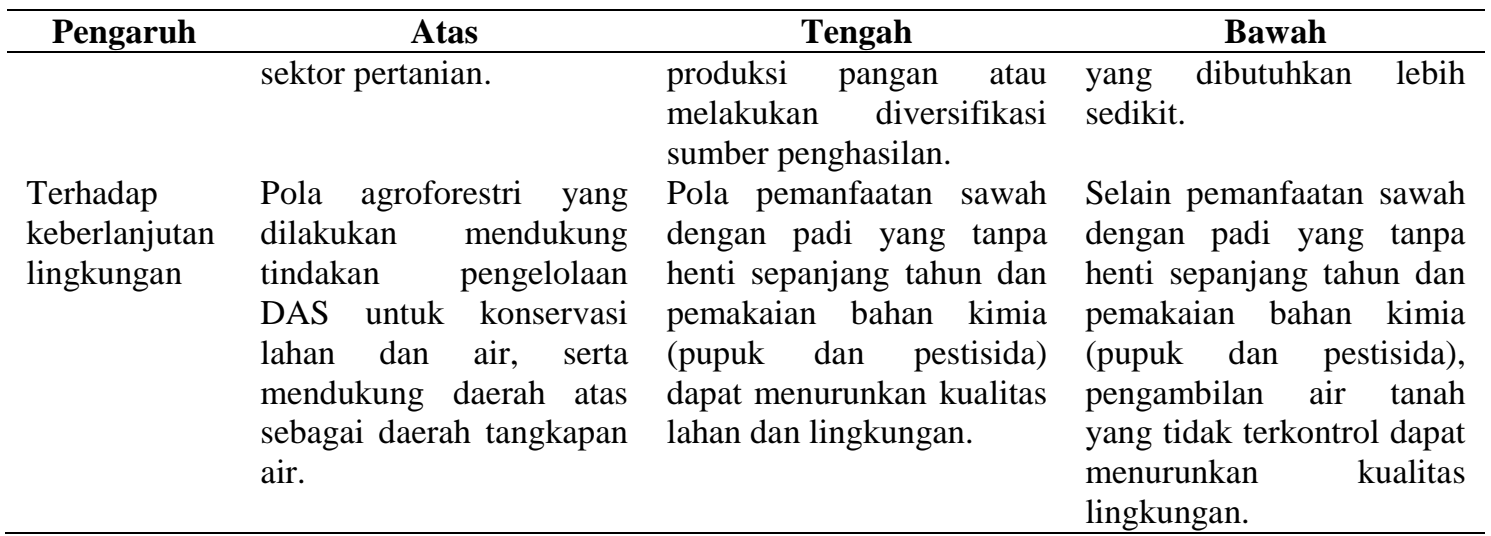

\section{Kesimpulan}

Aset penghidupan paling menonjol di Sub DAS Pusur dimiliki oleh Sub DAS bagian tengah dengan nilai total 28,07. Nilai modal paling rendah adalah modal finansial di Sub DAS bagian bawah yaitu sebesar 2,42. Sementara itu, modal fisik di Sub DAS bagian atas memiliki nilai paling tinggi yaitu 7,56. Secara umum, modal fisik mempunyai nilai paling tinggi di semua bagian sub DAS.

Strategi penghidupan berkelanjutan masyarakat untuk kegiatan intensifikasi dan ekstensifikasi pada bagian atas berupa kegiatan pengoptimalan hasil lahan dengan sistem agroforestri, pada bagian tengah dan bawah intensifikasi dilakukan dengan panca usaha tani.Strategi diversifikasi pada bagian atas didominasi dengan beternak khususnya sapi perah, sedangkan bagian tengah dan bawah didominasi dengan menjadi buruh/ karyawan. Strategi migrasi dengan alasan menikah dominan untuk bagian atas dan bawah. Sedangkan bagian tengah migrasi karena alasan pekerjaan.

\section{Daftar Pustaka}

Abdurrahim, A. Y. (2015). Kerentanan ekologi dan strategi penghidupan rumah tangga petani di Pantai Utara Indramayu (Unpublished master's thesis). Sekolah Pascasarjana Institut Pertanian Bogor, Indonesia.

Bank Dunia. (2010). Adaptasi terhadap perubahan iklim. Retrieved from http://siteresources.worldbank.org/INTINDONESIA/Resources/Publication/2800161235115695188/5847179-1258084722370/Adaptasi.terhadap.Perubahan.Iklim.pdf.

Baiquni, M. (2006). Pengelolaan sumber daya perdesaan dan strategi penghidupan rumah tangga di Provinsi Daerah Istimewa Yogyakarta pada masa krisis (1998-2003) (Unpublished doctoral dissertation). Program Pascasarjana, Universitas Gadjah Mada, Yogyakarta, Indonesia.

Bappeda Kabupaten Klaten. (2010). Rencana Tata Ruang Wilayah Kabupaten Klaten tahun 2011 - 2031. Klaten: Bappeda Kabupaten Klaten.

DFID. (1999a, 2000d, 2001). Sustainable livelihoods guidance sheets. Retrieved from www.livelihoods.org.

Ellis, F. (2000). Rural livelihoods and diversity in developing countries.Oxford: Oxford University Press.

Fraenkel, J. R, \& Wallen, N. E. (1993). How to design and evaluate research in education. Singapore: McGrawHill.

Gay, L. R., \& Diehl, P. L. (1992). Research methods for business and management. New York: Macmillan.

Meida, A. N. (2012). Konflik antar sektor di Kabupaten Klaten. Retrieved fromhttp://www.kompasiana.com/avidnurmeida/konflik-antarsektor-di-kabupatenklaten_551077c6a333119737ba82e8. 


\section{Strategi Penghidupan Berkelanjutan Masyarakat Berbasis Aset di Sub DAS Pusur, DAS Bengawan Solo}

Mukbar, D. (2009). Studi literatur dalam penelitian from rural to global labor: Transnational migration and agrarian change in indonesia and the philippines. Kerjasama Yayasan AKATIGA Bandung dan Department of Geography University of the Philippines.

Mulyatun. (2016). Sumber Energi Terbarukan dan Pupuk Organik dari Limbah Kotoran Sapi. Jurnal DIMAS, $16(1), 19-214$.

Pandit, B. H., Wagley, M.P., Neupane, R. P., \& Raj, B. (2007). Watershed management and livelihoods: Lesson from Nepal. Journal of Forest and Livelihood, 6(2), 67-75.

PDAM Kota Solo. (2016). Homepage PDAM Kota Surakarta. Retrieved from http://www.pdamsolo.or.id/content/sejarah-pdam-kota-surakarta.

Saleh, E. (2016). Strategi penghidupan penduduk sekitar Danau Limboto Provinsi Gorontalo (Unpublished doctoral dissertation). Program Pascasarjana, Universitas Gadjah Mada, Yogyakarta, Indonesia.

Saragih, S. Lassa, J., \& Ramli, A. (2007). Kerangka penghidupan berkelanjutan (Sustainable livelihood framework). Retrieved from http://www.zef.de/module/register/media/2390_SL-Chapter1.pdf

Scale Up. (2011). Konflik sumber daya alam dan penghidupan yang berkelanjutan. Buletin Scale Up, II, 1-4. Retrieved from http://www.forestpeoples.org/sites/fpp/files/news/2012/02/WebBuletinFord_02_2011.pdf.

Scoones, I. (1998). Sustainable rural livelihoods: A framework for analysis. Working Paper No. 72. Retrieved from https://www.staff.ncl.ac.uk/david.harvey/AEF806/Sconnes1998.pdf.

Sosiawan, H., \& Kartiwa, B. (2011). Pengelolaan sumber daya air terpadu di Kabupaten Klaten, tinjauan dari aspek hidrologi. Buletin Hasil Penelitian Agroklimat dan Hidrologi, 8, 41-45.

Surya, Sardi, I., \& Aprolita. (2015). Penerapan teknologi oleh petani dalam usaha tani padi sawah pada program gerakan serentak tanam padi dua kali per tahun di Desa Simpang Datuk Kabupaten Tanjung Jabung Timur. Jurnal Sosio Ekonomika Bisnis, 18(1), 72-82.

White, B. (1991). Economic diversification and agrarian change in rural Java 1900-1990. In Paul Alexander, P. Boomgaard, and B. White (Eds.), In the shadow of agriculture: Non-farm activities in the Javanese economy, past and present (pp.41-69). Amsterdam: Royal Tropical Institute. 